\title{
E-Learning Degree Programs - A Better Way to Balance Work and Education?
}

\author{
http://dx.doi.org/10.3991/ijac.v8i3.4844 \\ Claudia Moessenlechner, Regina Obexer, Karin Sixl-Daniell and Juergen-Matthias Seeler \\ Management Center Innsbruck, Innsbruck, Austria
}

\begin{abstract}
In the year 2011, in the USA alone, over seven million students were taking at least one online course in the tertiary educational sector. ICT-supported degree programs allow students to work on a more flexible schedule as regards time and location, which makes such programs especially attractive for working students. At the same time, such programs require greater effort and skills in terms of personal organization and study skills. As employees' willingness and ability to engage in lifelong learning and continuing professional development become core success factors for businesses world-wide, these aspects gain critical relevance.
\end{abstract}

This study looks at a cohort of 46 online students enrolled in a Bachelor of Business Administration degree in Austria. The students, most of whom are pursuing their first degree whilst working, come from Austria, Germany, Italy and Spain, and are on average 28 years of age. The BBA program (Bachelor Business Administration) is conducted in a blended learning mode, with up to ten days of face-to-face sessions per semester.

The main aim of this study is to explore the motivational factors of working students during the first phase of a blended learning degree program and investigate the main difficulties and challenges students perceive when having to organize and balance online education and full time work.

The results and implications of this study will be presented at the conference with suggestions for future research provided.

Index Terms-Working professionals, continuous education, lifelong learning, E-learning degree programs, online learner expectations, motivation.

\section{INTRODUCTION}

In tertiary education, the growth of the Internet and related technologies has led to a substantial change of teaching and learning practices as well as to a whole range of 'new' degree programs using E-learning technologies, online resources and collaboration tools, which have given distance education a new momentum [1]. This development is also apparent in Europe. Whilst distance education has a different tradition in Europe [2] compared to countries like Australia, New Zealand and the United States, distance education approaches are now becoming increasingly popular as they open up new opportunities in terms of the market and meet the needs of a diverse student population.

In Europe, higher education (HE) institutions are facing challenges and diversification of student populations due to several reasons. These are e.g. demographic changes in that most countries face an overall decrease in population growth and an overall aging population, an increased mobility of young people (brain drain) due to globalization leading to less skilled workers or students in (some) European countries, and increased demand for international employability in terms of skills and competencies. Added to this, growing economic constraints and changing demands in the job markets have significantly altered traditional career- and life-paths over the last decade. In Europe, this means that it is especially young, skilled workers with work experience that have the best opportunities in the job market. This opens an additional market for HE institutions, which are now catering for students who work alongside their studies, and also offer education in the context of continuing professional education and lifelong learning.

These developments have a significant impact on student profiles in that student cohorts tend to show a greater variety in terms of age, professional experience, family obligations, in their choice of study location, style of habitation, and in terms of not feeling forced to allocate their study period to a certain point in their life [3]. Similarly, Dabbagh [4] challenges the traditional notion of the distance learner as homogenous and unchanging, and contends that "the current profile of the online distance learner can be characterized as emerging, responsive to rapid technological innovations and new learning paradigms, and progressively including a younger age bracket." (p. 218). In the context of this study, E-learning is viewed as an umbrella term for technology enhanced learning and teaching that takes place online, i.e. specifically uses learning platforms and the Internet. Following Bates [5], online learning could also be seen as 'a subcategory of distance education' [6]. E-learning has a number of benefits, especially when it comes to overcoming restrictions related to time and location [7]. These two factors are especially relevant for part-time student cohorts in Elearning degree programs, a growing student population in Europe.

A growing trend in higher education is blended learning $[8,9]$. Blended learning denotes a teaching and learning model that combines traditional classroom lectures with synchronous and asynchronous online teaching. The merits of blended learning are obvious: personal teacherlearner interaction is regularly included in the programs, thus countering the disadvantages of pure online learning programs. With online and classroom lectures, podcasts, discussion boards, and guided forums, blended learning offers a range of different facilitation modes $[10,11]$. 


\section{StUdent Motivation In E-LEARning}

Despite the obvious advantages of distance education programs, attrition rates are significantly higher in these programs compared to traditional on-campus programs. Literature identifies a number of factors that are vital for student success in such programs. One of the most important factors is student motivation $[12,13]$. In fact, a lack of student motivation is often cited as the cause of high drop-out rates in E-learning programs, which leads to the assumption that online learners are not as 'independent, self-directed, and intrinsically motivated' as literature often claims [14].

Motivation can be defined as ,the process whereby goal-directed activity is instigated and sustained" [15]. It has been shown that intrinsically motivated students tend to outperform those with little intrinsic motivation; however, studies have shown that intrinsically motivated students do not necessarily work harder than their nonintrinsically motivated peers, rather they do different things [16] and display more explorative study behavior [17], supporting the results of other studies stating that high intrinsic motivation is positively correlated with curiosity and exploration $[18,19,20]$. Studies have been primarily focusing on traditional settings when investigating the role of motivation in learning, however, lack of motivation is a major factor in drop-out rates in online courses [21] and is a key factor in E-learning [22, 23, 24, 25].

Studies that looked at motivation in E-learning specifically found that students in E-learning environments were motivated [26] and that E-learning was at least as effective as learning in traditional settings, with contents, methods, and support services playing a crucial role in motivation and satisfaction of students - more so than technology [27]. Blended learning students were described as better satisfied and more intrinsically motivated than traditional students in a number of studies [28, 29, 30].

\section{SUCCESS FACTORS FOR ONLINE STUDENTS}

Numerous studies document the main success factors for online students in addition to motivational aspects. One study [31] found that there are four main aspects determining study success for online students: time, technology, initiative and competence, with time being the most significant: "The two most commonly identified factors are timely, active involvement in the course [...] and effective time management [...]" (p. 6). Initiative refers to personal drive to learn and seek assistance, selfmotivation and self-initiation, as well as a positive attitude, and is also related to metacognitive skills (selfmonitor learning, initiate learning, ask questions). The third factor, technology, relates to digital literacy and the ability to work comfortably in an online learning environment, including information literacy skill. Competence encompasses cognitive abilities, including reading comprehension, writing skills, communication skills as well as awareness of expectations and organizational skills. In addition to these four key factors, the authors also discuss personal factors (support from family and work as well as health) and instructor support.

Similar factors are identified by Yukselturk \& Bulut [32], who stress the importance of self-regulation in learning through metacognitive, motivational and behavioral aspects, and the need to provide learners with clear infor- mation about expectations and the nature of online learning. Additionally, they emphasize the role of interaction (particularly amongst students), and instructional strategies such as providing effective feedback, monitoring performance, and relevant, authentic content in rich formats. Dabbagh [33] lists a similar set of success factors, emphasizing skills in using online learning and communication technologies, having a "strong academic selfconcept," (p. 221) as well as interpersonal and communication skills, awareness of collaborative learning and necessary skills, and self-regulated learning skills (including time management and cognitive learning strategies).

Examining barriers to success in online learning, Muilenburg \& Berge [34] found that the main issue identified as impeding successful studying online was social isolation, followed by administrative and instructor issues, learner motivation, and time and/or support for studies ( $\mathrm{p}$. 38). It is interesting to note that the first barrier, lack of social interaction, was rated significantly higher than the other barriers. The authors observe: "The findings here are that social interaction is strongly related to online learning enjoyment, effectiveness of learning online, and the likelihood of taking another online class." (p. 45).

In summary, literature is consistent with regards to what it takes to be a successful online learner, albeit with different emphasis on success factors. The key to successful online learning lies in a combination of (mainly intrinsic) motivation, self-regulation and meta-cognitive skills, realistic expectations of the requirements of online study, time management, strong communication skills and the ability to successfully engage in an online community. External support also plays a significant role.

\section{RESEARCH}

Building on the literature review outlined above, this paper presents findings from a qualitative study that explored expectations regarding challenges and difficulties defined by students in a blended learning program when organizing and balancing their personal education and mostly full time work, as well as their motivations for study.

\section{A. Participants and Context}

The course that provided the context for the present study was situated within the larger context of a blended learning undergraduate degree program in Business Administration in Austria.

Online learning is organized in synchronous and asynchronous mode i.e. students have direct, live contact with other students as well as the lecturer on some days, and also work independently with resources available online or the learning management system. In the present program, students have 2 weekly synchronous online sessions where the lecturer is present by means of webconferencing software and uses a variety of both synchronous and asynchronous interaction strategies (discussion boards, chats, email, VoIP). As a blended learning model, the program combines face-to-face events with online learning and teaching. All in all, there are up to 10 days per semester that are taught in face-to-face mode or are used for examination purposes.

This combination of synchronous online presence, oncampus teaching and asynchronous, independent student learning is a distinguishing feature of the program. The blended learning model combines key benefits of E- 
learning, namely the flexibility of learning, the possibility of coaching during self-organized learning phases, student interaction and learning and teaching through incorporating educational technology.

As in E-learning self-management and independent study skills are vital for success, the curriculum includes an introductory course on online learning. This course provided the framework to gather data sets for the present analysis as students submitted an assignment in form of a reflection paper. They were given the task to consider and describe their personal motivation and strategy for successfully completing the program, based on the course content discussed and activities. These reflections were used as the main data set for analysis.

Students were not asked to follow a specific structure in their reflection. Additionally, they were given the opportunity to discuss relevant matters in the discussion board on the course site.

The sample group is composed of the first cohort of 46 students from the newly established E-learning-based study program (Bachelor Business Administration) delivered in blended learning mode. Students come from Austria, Italy, Spain, and Germany. The average age is 28 (between 19 and 45 years old) with 33\% female and $67 \%$ male students.

\section{B. Research Design}

The overall methodological approach is based on a research paradigm of constructivism [35]. This means reality is understood as individually created based on a person's experiences, attitudes and perspectives [36, 37]. The study aims at exploring "challenges", "difficulties", and "motivators" of working students enrolled in a blended learning degree program. These concepts were not rigorously defined and depend on the perspective of the individual. Therefore, qualitative research methods are favored as these methods deliberately include the researcher's subjectivity to understand a phenomenon - in this case expectations, motivators and difficulties perceived by students [38].

A key question in qualitative research is whether the data collection strategy is appropriate in regard to the research questions [39]. As students did not only express their perspectives but also discussed the issues on discussion boards, social interaction among students as well as contextual influences had an impact on students' statements - an added advantage in qualitative research in that it helps to generate rich data $[40,41,42]$.

The main questions authors looked at in their content analysis of students' reflection papers were:

What main motivators drive online students during their first phase of studies and what are the main difficulties and challenges students perceive when having to organize and balance online education and full time work?

This study employs "Qualitative Content Analysis" [43] for data analysis. Categories for coding were defined following an inductive approach [44]. Three coders were working closely with the material (reflection papers) in order to identify categories emerging from the material. First, coders went through the materials individually and analyzed the data to then identify themes to address the research question. It was agreed to only look for very explicit comments. In a second step, coding tables referring to the now emerging categories were compared and consolidated, and a subsumption of categories took place to guarantee formative reliability. A final analysis of all research data guaranteed summative reliability and allowed for a summative analysis as well as a comparison with literature.

As the student reflection papers were written in German, direct quotes from students in the following were translated into English by the authors.

\section{RESUlTS}

The following tables present the results of the summative qualitative analysis of the 46 reflection papers. They address the questions of what main motivators drive online students during their first phase of studies, and what key difficulties and challenges they perceive when organizing and balancing online education and full time work.

\section{A. Motivators}

Whilst students have varying backgrounds with regards to their professional experience and work alongside studying, it became apparent that motivators for taking up a blended learning study program were fairly consistent amongst the group. The majority of students expressed an interest in the program's content and curriculum as being a main motivator to study. The relevance of content for their own professional context was explicitly mentioned several times, and students frequently pointed out promotion possibilities at work, monetary gains and job security as well as professional recognition.

Also, the difference between 'having to learn something and wanting to learn something' was made explicit several times. One student mentioned that this differentiation helps him to show initiative and generate motivation.' The distinction was mainly made in the context of comparing studying in their current degree with the experience of studying at high school/college. The hope to be able to immediately apply newly learned skills and competencies in the work environment was expressed. Several students described setting specific (learning) goals in life as a motivational factor and referred to lifelong learning as a specific objective in their lives.

Several students commented on the relationships they built with others both in the face-to-face events as well as on the discussion boards as motivational factor. Reasons cited include that there is much to be gained from an academic as well as a social perspective and this, in turn, helps to stay focused, motivated and to feel less 'lonely'. This is consistent with other research that emphasizes the importance of social presence and connection as a key motivating factor for online learners $[45,46]$.

\section{TABLE I. MOTIVATORS}

\begin{tabular}{|c|c|}
\hline \multicolumn{2}{|c|}{ Motivators } \\
\hline $\begin{array}{l}\text { This category contains } \\
\text { student comments } \\
\text { relating to intrinsic and } \\
\text { extrinsic motivational } \\
\text { factors they see affect- } \\
\text { ing their studies. }\end{array}$ & $\begin{array}{l}\text { - Inherent interest in content } \\
\text { - } \quad \text { Relevance of content } \\
\text { Lifelong learning } \\
\text { Direct application of new } \\
\text { knowledge to work situation } \\
\text { Recognition by others } \\
\text { Job security and career pro- } \\
\text { spects } \\
\text { - Monetary gains } \\
\text { Enjoyment of connecting with } \\
\text { others }\end{array}$ \\
\hline
\end{tabular}




\section{B. Time- and self- management}

All students strongly emphasized the importance of time management skills and referred to explicit time management techniques that are helpful for them to manage their workload. SMART goal setting, the ability to prioritize and plan as well as scheduling techniques were discussed several times.

It also became apparent that, although working in formalized professional settings, many students have had only little or no experience with or knowledge of time management concepts or theories. This could be a reason why this issue was extensively discussed also on the course discussion board. One student mentioned in the reflection paper: I have never thought about time management in my life. The discussions/input helped me to not only structure and manage workload for my studies but is also effective and useful in my job. The importance of time management techniques as a support to achieve a balance between studying, working and leisure time was pointed out by most students as being especially important in the context of online studies.

It is interesting to note that in the context of time- and self-management, several students were referring to digital tools and applications they are using or planning to use to manage their workloads. There were a number of students who explicitly mentioned that they use a pencil-paper approach for planning purposes, mainly due to the fact that they do not only want to use digital tools for their learning.

Several students also commented on their learning environment, saying they realized that they needed a suitable space for their studies. The use of music as well as using mobile technologies for "learning on the go" was also mentioned.

TABLE II. TIME- AND SELF-MANAGEMENT

\begin{tabular}{|c|c|c|}
\hline \multicolumn{3}{|c|}{ Time- and self-management } \\
\hline $\begin{array}{l}\text { This category encom- } \\
\text { passes concepts related } \\
\text { to student strategies to } \\
\text { plan and use their time } \\
\text { effectively and pro- } \\
\text { ductively. }\end{array}$ & & $\begin{array}{l}\text { Scheduling fixed blocks of } \\
\text { time for learning, work, family, } \\
\text { leisure } \\
\text { Use of digital tools for time } \\
\text { management } \\
\text { - Realistic goal setting } \\
\text { - } \quad \text { Prioritizing } \\
\text { - } \quad \text { Start early } \\
\text { Effective use of unproductive } \\
\text { time } \\
\text { Importance of learning envi- } \\
\text { ronment }\end{array}$ \\
\hline
\end{tabular}

\section{Study skills, cognitive strategies and collaborative learning}

Similar to the discussion around time management, students also explicitly mentioned techniques to help them learn, both in terms of cognitive strategies (e.g. using mindmaps, directly applying knowledge to their own situation, etc.) and in terms of format (e.g. recording study materials for use on mobile phones, learning whilst on public transport, etc.).

It became apparent that some students took a reflective approach to their studies and had a high degree of selfawareness in terms of how they learn best (metacognitive skills) whereas others had not reflected on their learning styles previously. Several students referred to the fact that they learn differently compared to their study approaches at high school/college and that they recognize a change in terms of learning styles. Many mentioned that they have never enjoyed rote learning and commented that peer discussions helped create and contextualize knowledge.

A majority of students stressed the importance of working with their peers and in a team as a factor for successful learning.

Students mentioned explicitly that peer discussions help understand and create meaning together and to gain knowledge from connecting with others. These discussions were perceived as enriching from both a social as well as an academic perspective: 'I am thrilled how many viewpoints can be created through connecting with others', and 'I am surprised about the engagement of my peers and their valuable input during face-to-face sessions and online discussions'. Students mentioned an explicit motivation to do more research on a topic when it was brought up by a student peer. Also, they felt that input from student peers made them reflect on content more and thus it gained a higher relevance for them personally which led to a reconsideration of their own habits (e.g. regarding time management). One student talked about 'a shift in direction' triggered by an online discussion post.

The fact that discussions are possible at any given time through the university's Learning Management System was seen as positive in terms of personal time schedules but also because it was perceived as being 'easier to e.g. ask questions as in a face-to-face situation it could be more embarrassing to ask'.

One student mentioned that discussion boards help to concentrate as there is less distraction and 'noise' in online learning environments.

TABLE III. STUDY SKILLS, COGNITIVE STRATEGIES, AND COLLABORATIVE LEARNING

Study skills, cognitive strategies, and collaborative learning - $\quad$ Awareness of different (and own) learning styles

This category refers to explicit and implicit mentions of student perceptions of skills related to studying, related to knowing how they study, and first perceptions of collaborative learning.

- Reflection on previous study experience

- $\quad$ Awareness of need to selfregulate

- Defining SMART goals

- Application of new knowledge

- Use of digital tools for learning

- Realization of benefits of learning with others

- Social and academic perspective of connecting with others

\section{Challenges}

In their reflection papers most students referred to finding a life-work-study-balance as the main challenge they are facing. All of them referred to time management activities as a possible, useful support to overcome these difficulties. Many mentioned that they are still trying to find a planning approach that works for them. Students mentioned an explicit connection between efficient time management and motivation for their studies. Structuring one's work not only in a study context, but also in their jobs and private lives was seen as a significant element to be successful. The issue of delegating work to others in 
the work environment was brought up several times. A few students mentioned the online learning environment and using technology as being a challenge for them. Overall, there was a positive tenor across all reflections, with students acknowledging the challenges of their undertaking to study and work but at the same time having a range of strategies to overcome these.

TABLE IV. STUDY SKILLS, COGNITIVE SKILLS, AND COLLABORATIVE LEARNING

\begin{tabular}{|c|c|}
\hline \multicolumn{2}{|c|}{ Perceived challenges } \\
\hline $\begin{array}{l}\text { This category sub- } \\
\text { sumes student com- } \\
\text { ments regarding the } \\
\text { challenges they expect } \\
\text { or perceive with } \\
\text { regards to their study. }\end{array}$ & $\begin{array}{c}\text { - } \\
\text { - } \\
\text { Poor time management habits } \\
\text { (last minute) } \\
\text { - } \quad \text { Making the time to study } \\
\text { Motivation over time } \\
\text { - } \quad \text { False perception of "I know } \\
\text { this already" } \\
\text { New learning environment }\end{array}$ \\
\hline
\end{tabular}

\section{CONCLUSION AND DISCUSSION}

This study confirms several aspects well documented in literature, however there are also a number of findings which suggest further exploration and research.

As mentioned above, literature suggests that intrinsically motivated students do not need additional motivational factors from outside like rewards or other external triggers. This is partly in contrast with the results of this study as students mention extrinsic motivational factors i.e. they describe motivational reasons that are not part of the mere activity of studying. The present results suggest that external motivational drivers are especially relevant for working students as e.g. obtaining formal qualifications for career progression, job security and monetary gains, and the possibility to immediately apply new knowledge are explicitly mentioned as motivations to study online. This points to an even stronger focus on practical relevance of knowledge in program curricula and instructional design of online university programs. Furthermore, an educational approach that allows students to be interactive and study collaboratively seems to be a trigger for keeping motivation up and continuing studies. This confirms the advantage of such an approach, also in view of high dropout rates in online programs.

Good time management skills are an important success factor for a positive completion of online studies. Bearing the workload and multiple commitments of working students in mind, this seems to be all the more significant for this specific cohort. The present study suggests that it is especially these skills students seem to have difficulties with or describe as the major challenge when it comes to studying online. This points to the importance of including self- and time management skills in the mandatory curriculum rather than teach these skills only in extra-curricular offers.

The role of interaction amongst students when learning cannot be underestimated, especially because collaborative learning environments can help prevent social isolation leading to possible student drop-outs. Although it is not suggested that interactive learning environments automatically lead to positive program completion, the strong and positive remarks of students regarding online interaction suggest that it adds to successful learning and online learning enjoyment.
There are a number of limitations in this study. First, the sample for this study was limited to 46 students in a single degree program. Secondly, the students primarily come from one cultural background which might have an impact on their reflections.

Building on the qualitative research conducted here, further research will be carried out with the same student cohort to investigate how their perceptions change over the course of the program. Additionally, the next student cohorts commencing the program will be subject to similar research in order to establish recurring themes over a period of time.

Future research should extend the scope of data collection to include students from further cohorts and further degree programs. Additionally, future research can expand to a variety of geographies to further investigate the generalizability of these findings. Furthermore, it would be interesting to see if the professional background of students has an impact on findings, i.e. are there differences in perceptions for engineers/marketing professionals etc.

Ultimately, these research efforts are intended to collate a rich set of longitudinal data about expectation, motivation and perceptions of learners in professional contexts. The results of this research can inform and directly influence the design of blended learning degree programs for working students, and the supports they need to be successful. In light of the growing number of working students and the increasing requirement to enable working people to participate in continuing education, this is an important area of future research.

\section{REFERENCES}

[1] Hartnett M., St. George A. and Dron J., "Examining motivation in online distance learning environments: complex, multifaceted, and situation-dependent." IRRODL The International Review in Open and Distance Learning. 2011, 12 (6), pp 21-37.

[2] Ruegg W., ed. A History of the University in Europe, Vol.4. Cambridge: Cambridge University Press, 2011.

[3] Humpl S., Luomi J., Ferrandez-Berrueco M. R., Mothersdale J., Prösel S., Surdej A. et al., Lifelong Learning in Higher Education, Different Aspects Discussed in the ProParti Project (Leonardo da Vinci Partnership No. 2009-1-AT1-LEO04-01505 1 Final Report, July 2011.

[4] Dabbagh, N., "The online learner: Characteristics and pedagogical implications." Contemporary Issues in Technology and Teacher Education. 2007, 7 (3), 217-226

[5] Bates, A. W., Technology, e-learning and distance education (2nd ed.). New York: RoutledgeFalmer., 2005. http://dx.doi.org/10.4324/9780203463772

[6] Hartnett M., St. George A. and Dron J., "Examining motivation in online distance learning environments: complex, multifaceted, and situation-dependent", IRRODL The International Review in Open and Distance Learning. 2011, 12 (6), pp 21-37.

[7] Bates, A. W., Technology, e-learning and distance education (2nd ed.). New $\quad$ York: 2005. http://dx.doi.org/10.4324/9780203463772

[8] Fearon, C., Starr, S., McLaughlin, H., "Value of blended learning in university and the workplace: some experiences of university students", Industrial and Commercial Training. 2011, 43 (7), pp. 446 - 450. http://dx.doi.org/10.1108/00197851111171872

[9] Fearon, C., Starr, S., McLaughlin, H., "Blended learning in higher education (HE): conceptualising key strategic issues within a business school", Development and Learning in Organizations: An International Journal. 2012, 26(2), pp. $19-22$. http://dx.doi.org/10.1108/14777281211201196

[10] Fearon, C., Starr, S., McLaughlin, H., "Value of blended learning in university and the workplace: some experiences of university students", Industrial and Commercial Training. 2011, 43 (7), pp. 446 - 450. http://dx.doi.org/10.1108/00197851111171872 
[11] Fearon, C., Starr, S., McLaughlin, H., "Blended learning in higher education (HE): conceptualising key strategic issues within a business school", Development and Learning in Organizations: An International Journal. 2012, 26(2), pp. 19 - 22. http://dx.doi.org/10.1108/14777281211201196

[12] T.A. Bekele, "Motivation and satisfaction in internet-supported learning environments: A review", Educational Technology \& Society, vol. 13 (2), pp116-127, 2010.

[13] Yukselturk, E. and Bulut, S.,’Predictors for Student Success in an Online Course", Educational Technology \& Society. 2007,10 (2), 71-83.

[14] Hartnett M., St. George A. and Dron J., "Examining motivation in online distance learning environments: complex, multifaceted, and situation-dependent", IRRODL The International Review in Open and Distance Learning. 2011, 12 (6), pp 21-37.

[15] Schunk, D. H., Pintrich, P. R., and Meece, J. L., Motivation in Education (3rd ed.). Upper Saddle River, NJ: Pearson Merrill Prentice Hall, 2008

[16] Martens R.L., Gullikers J. and Bastiaens T., "The impact of intrinsic motivation on e-learning in authentic computer tasks", Journal of Computer Assisted Learning. 2004, pp. 1-9. http://dx.doi.org/10.1111/j.1365-2729.2004.00096.x

[17] Garris R., Ahlers R, Driskell J.E., "Games, motivation and learning: a research and practice model", Simulation and Gaming. 2002, 33, pp. 441-467. http://dx.doi.org/10.1177/ 1046878102238607

[18] Ryan R.M. and Deci E.L., "Self-determination theory and the facilitation of intrinsic motivation, social development and wellbeing”, American Psychologist. 2000,55, pp. 68-78. http://dx.doi.org/10.1037/0003-066X.55.1.68

[19] Cordova D. and Lepper M., "Intrinsic Motivation and the process of learning: beneficial effects of contextualization, personalization and choice", Journal of Educational Pychology. 1996, 88, pp. 715-730. http://dx.doi.org/10.1037/0022-0663.88.4.715

[20] Vallerand R., Fortier M.S., Guay F., "Self-determination and persistence in a real life setting: toward a motivational model of high school drop out", Journal of Personality and Social Psychology, 1997, 72, pp. 1161-1176. http://dx.doi.org/10.1037/00223514.72.5.1161

[21] Muilenburg, L. Y., and Berge, Z. L. „Student barriers to online learning: A factor analytic study", Distance Education. 2005, 26(1), 29-48. http://dx.doi.org/10.1080/01587910500081269

[22] Jones, A., and Issroff, K., "Learning technologies: Affective and social issues". In G. Conole and M. Oliver (Eds.), Contemporary perspectives in e-learning research: Themes, methods and impact on practice. London: Routledge, 2007

[23] Keller, J. M., "Motivation in cyber learning environments", International Journal of Educational Technology. 1999, 1(1), pp. 7-30.

[24] Sankaran, S. R. and Bui, T., "Impact of learning strategies and motivation on performance: A study in web-based instruction", Journal of Instructional Psychology. 2001, 28(3), pp. 191-198.

[25] Song, S. H., "Research issues of motivation in web-based instruction", Quarterly Review of Distance Education. 2000, 1(3), 2pp. 25-229.

[26] Artino A.R., "Motivational beliefs and perceptions of instructional quality: predicting satisfaction with online training", Journal of Computer Assisted Learning. 2008, 24, pp. 260-270 http://dx.doi.org/10.1111/j.1365-2729.2007.00258.x

[27] Bekele, T. A., "Motivation and Satisfaction in Internet-Supported Learning Environments: A Review", Educational Technology \& Society. 2010, 13 (2), pp. 116-127.

[28] Whiting M., Liu J. and Rovai A.P., "Distinguishing sense of community and motivation characteristics between online and traditional college students", The Quarterly Review of Distance Education, 2008, 9(3), pp. 285-295.

[29] Shroff R., Vogel D., "Assessing the Factors Deemed to Support Individual Student Intrinsic Motivation in Technology Supported Online and Face-to-Face Discussions", Journal of Information Technology Education. 2009, (8), pp. 59-58.

[30] Rovai A., Ponton M., Whiting M. and Baker J., "A Comparative Analysis of Student Motivation in Traditional Classroom and ELearning Courses", International Journal on E-Learning. 2007, 6(3), pp. 413-432.

[31] Mandernach, B., Donnelli, E. and Dailey-Hebert, A., "Learner Attribute Research Juxtaposed with Online Instructor Experience:
Predictors of Success in the Accelerated, Online Classroom", The Journal of Educators Online. 2006, 3 (2).

[32] Yukselturk, E. and Bulut, S., "Predictors for Student Success in an Online Course", Educational Technology \& Society. 2007, 10 (2), pp. 71-83.

[33] Dabbagh, N., "The online learner: Characteristics and pedagogical implications", Contemporary Issues in Technology and Teacher Education. 2007, 7 (3), pp. 217-226.

[34] Muilenburg. L. and Berge, Z., "Student Barriers to Online Learning: A factor analytic study", Distance Education. 2005, 26 (1). 29-48. http://dx.doi.org/10.1080/01587910500081269

[35] Guba, E. G. and Lincoln, Y. S., "Competing Paradigms in Qualitative Research", in Denizen, NK and Lincoln, YS (eds.), Handbook of Qualitative Research, Sage Publications, Thousand Oaks, 1994.

[36] Guba, E. G. and Lincoln, Y. S., "Competing Paradigms in Qualitative Research", in Denizen, NK and Lincoln, YS (eds.), Handbook of Qualitative Research, Sage Publications, Thousand Oaks, 1994.

[37] Kitzinger, C., "Feminist Approaches", in: Seale, C., Gobo, G., Gubrium, J., Silverman, D. Qualitative Research Practice, Sage Publications, London, 2004. http://dx.doi.org/10.4135/97818 48608191.d12

[38] Soeffner, H. G., „Sozialwissenschaftliche Hermeneutik“, in: Flick, U., von Kardorff, E., Steinke, I., Qualitative Forschung, Rowohlt, Reinbeck, 2007.

[39] Silverman, D., Interpreting Qualitative Data, Sage, London, Thousand Oaks, 2006.

[40] Yin, R. K., Case study research: Design and methods, Applied Social Research Methods Series, $2^{\text {nd }}$ edition, Sage Publications, Thousands Oaks, 1994.

[41] Miller, J. and Glassner, B., "The "inside" and the "outside": finding realities in interviews", in: Silverman, D. (ed), Qualitative Research: Theory, Method and Practice, Sage, London, 2004.

[42] Rapley, T., "Interviews", in Seale, C., Gobo, G., Gubrium, J., and Silverman, D. (eds.), Qualitative Research Practice, Sage Publications, London, 2004. http://dx.doi.org/10.4135/9781848608191.d5

[43] Mayring, P., „Qualitative Inhaltsanalyse. Grundlagen und Techniken“, $6^{\text {th }}$ edition, Beltz, Weinheim, 2000. http://dx.doi.org/10.1007/978-3-8349-9258-1 42

[44] Mayring, P., „Qualitative Inhaltsanalyse“. In: Flick, U., Kardoff, E., Steinke, I. (eds.), Qualitative Forschung, Rowohlt, Reinbeck, 2007.

[45] Standford-Bowers, D., "Persistence in Online Classes: A Study of Perceptions among Community College Stakeholders", MERLOT Journal of Online Learning and Teaching. 2008, 7 (1), 37-50.

[46] Bekele, T. A., "Motivation and Satisfaction in Internet-Supported Learning Environments: A Review", Educational Technology \& Society. 2010, 13 (2), pp. 116-127.

[47] Deci, E. L., Koestner, R., and Ryan, R. M., "Extrinsic rewards and intrinsic motivation in education: Reconsidered once again", $R e$ view of Educational Research. 2001, 71(1), 1-27. http://dx.doi.org/10.3102/00346543071001001

\section{AUTHORS}

Claudia Moessenlechner is with MCI Management Center Innsbruck/Learning Solutions, Innsbruck, Austria (e-mail: claudia.moessenlechner@mci.edu).

Regina Obexer is with MCI Management Center Innsbruck/Learning Solutions, Innsbruck, Austria (e-mail: regina.obexer@mci.edu).

Karin Sixl-Daniell is with MCI Management Center Innsbruck/Business Administration Online, Innsbruck, Austria (e-mail: karin.sixl@mci.edu).

Juergen-Matthias Seeler is with MCI Management Center Innsbruck/Business Administration Online, Innsbruck, Austria (e-mail: matthias.seeler@mci.edu).

This article is an extended and modified version of a paper presented at the International Conference on E-learning in the Workplace 2015 (ICELW'15), held in June 2015, at Columbia University in New York, NY, USA. Manuscript received 15 March 2015. Published as resubmitted by the authors 30 August 2015 . 